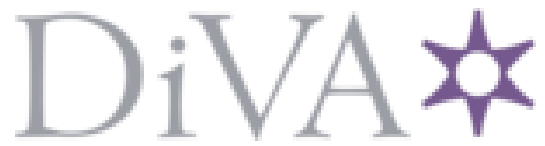

http://www.diva-portal.org

This is the published version of a paper published in Energy \& Fuels.

Citation for the original published paper (version of record):

Holmgren, P., Skoglund, N., Broström, M., Backman, R. (2020)

Slag Formation during Entrained Flow Gasification: Calcium-Rich Bark Fuel with $\mathrm{KHCO}_{3}$ Additive

Energy \& Fuels, 34(6): 7112-7120

https://doi.org/10.1021/acs.energyfuels.0co0753

Access to the published version may require subscription.

N.B. When citing this work, cite the original published paper.

Permanent link to this version:

http://urn.kb.se/resolve?urn=urn:nbn:se:umu:diva-174023 


\title{
Slag Formation during Entrained Flow Gasification: Calcium-Rich Bark Fuel with $\mathrm{KHCO}_{3}$ Additive
}

\author{
Per Holmgren, Nils Skoglund, Markus Broström,* and Rainer Backman \\ Cite This: Energy Fuels 2020, 34, 7112-7120 \\ Read Online
}

ABSTRACT: Slag property management is of utmost importance for successful operation of entrained flow gasifiers. The present study investigates the influence of potassium introduced as $\mathrm{KHCO}_{3}$ on the ash and slag formation of softwood bark, a calcium-rich fuel, during entrained flow gasification. The bark contained only minor mineral inclusions causing the ash composition to be dominated by calcium and potassium. Wood bark with and without $\mathrm{KHCO}_{3}$ additive was gasified between 850 and $1400{ }^{\circ} \mathrm{C}$ at $\mathrm{O}_{2}$ stoichiometric ratio $(\lambda) 0.6$. The ash particles collided with a flat impact probe inside the hot reactor at particle impact angles set to $90^{\circ}, 60^{\circ}$, and $30^{\circ}$. The reactor and probe allowed long-distance microscope data collection close to the probe surface. Particle deposition was optically monitored and resulting deposits were analyzed by SEM-EDS and XRD. Thermodynamic equilibrium and viscosity calculations were used to assist interpretation of experimental results. The predicted temperature window for liquid carbonate formation was experimentally verified, but the melt fraction of the deposit was too low to cause efficient flow and removal of ash from the probe under the prevailing experimental conditions. At higher temperatures, spherical particles indicated lower ash melting temperatures than expected from the bulk ash composition, and a detailed mechanism was proposed.

\section{INTRODUCTION}

Sustainable and economically viable entrained-flow gasification of woody biomass is a promising route for production of fossil free fuel and chemicals. ${ }^{1}$ Ash handling is of utmost importance for stable operation of slagging entrained flow gasifiers, mainly governed by the melting and flow properties of the ash. It is wellknown that the inorganic fuel composition determines ash properties and slag flow. Continuous removal of ash and slag from the reactor is necessary to prevent outlet blockage in entrained flow gasification. This can be achieved by establishing a steadily flowing slag tapped at the bottom of the reactor, an approach that is successfully employed in entrained-flow gasification of coal. ${ }^{2}$ The method has proven difficult to implement for calcium-rich biomass fuels due to unfavorable ash compositions from a slag flow perspective. ${ }^{3}$

Experiences from pilot scale gasification have determined that fractionation of ash forming elements occurs, complicating predictions of slag properties even further. ${ }^{4,5}$ In pilot-scale gasification of bark ${ }^{5}$ supported by thermochemical equilibrium calculations, ${ }^{4}$ it was shown that inclusion of quartz and feldspars in the bark were crucial for phase chemical composition as well as rheological slag properties. The chemical composition, and thereby inherent properties, of the slag was found to differ between wall deposits and bottom slag. The wall deposits were found to be depleted in potassium compared to the overall ash composition of the bark fuel. This directly affects slag properties and may possibly explain the poor slag flowability in bark gasification.

These phenomenons were observed in gasification of bark containing naturally occurring mineral inclusions. The prevalence of silicon from such minerals cause the silicate-dominated slag system to be most important. Entrained flow gasification using bark with minute mineral content are not well studied but could be of future relevance. ${ }^{6}$ For such barks, or commonly energy crops such as willow, calcium is the dominating ashforming element together with potassium. It is well-known that such fuels typically form carbonates or oxides during thermal conversion. ${ }^{7}$ Formation of carbonate-melts may be facilitated by the addition of potassium, a strategy employed to improve syngas yields in gasification. ${ }^{8}$

Thermodynamic equilibrium calculations on alkali-enriched fuels aiming to predict slag properties have been previously published $^{9,10}$ and sodium has received significant focus, especially in regard to black liquor gasification. ${ }^{11-13}$ Similarly, slag removal when using calcium rich fuels could in theory be achieved by forming large amounts of low-viscosity potassiumcalcium carbonates at relatively low reactor temperatures. Publications from empirical studies of such carbonate formation in entrained flow gasification are scarce whereas the silicate system has been published by several groups. ${ }^{14,15}$

The present study aims to provide new knowledge by experimentally determining the influence of increased potassium content on carbonate formation and their properties during entrained flow gasification of calcium rich spruce bark. Thermodynamic equilibrium and viscosity calculations were used to assist interpretation of experimental results.

Received: March 9, 2020

Revised: May 14, 2020

Published: May 27, 2020 


\section{METHOD}

2.1. Fuel Composition. Bark from Norway Spruce (Picea abies) was used in the present study. Low content of extraneous material (quartz and feldspars) enabled studying the ash forming reactions based on mainly the inherent content of ash forming elements. The low mineral content was achieved by milling and sieving to the preferred size range for fuel feed $(250-500 \mu \mathrm{m})$, where remaining mineral inclusions were almost completely removed with fine particles below the $250 \mu \mathrm{m}$ cutoff. This is supported by the low $\mathrm{Si}$ content reported in the fuel as analyzed using ICPOES/ICPMS according to EN 14775/15104/15289/ $15290 / 15297$, see Table $1 . \mathrm{KHCO}_{3}$ (>99.7\%, Sigma-Aldrich)

Table 1. Fuel Composition and Main Ash Forming Elements, on Dry Basis

\begin{tabular}{|c|c|c|c|}
\hline & & 0 & 5 \\
\hline $\mathrm{KHCO}_{3}$ & wt. \% & analyzed & calculated $^{a}$ \\
\hline $\operatorname{ash}\left(550^{\circ} \mathrm{C}\right)$ & wt. \% & 1.70 & 5.1 \\
\hline $\mathrm{C}$ & wt. \% & 50.6 & 48.7 \\
\hline $\mathrm{H}$ & & 6.0 & 5.7 \\
\hline $\mathrm{N}$ & & 2.5 & 2.4 \\
\hline $\mathrm{O}$ & & 41.5 & 41.8 \\
\hline S & $\mathrm{mg} / \mathrm{kg}$ & 278 & 265 \\
\hline $\mathrm{Cl}$ & & 72 & 69 \\
\hline $\mathrm{Al}$ & & 588 & 560 \\
\hline $\mathrm{Ca}$ & & 3720 & 3541 \\
\hline $\mathrm{Fe}$ & & 73 & 69 \\
\hline $\mathrm{K}$ & & 2070 & 20581 \\
\hline $\mathrm{Mg}$ & & 626 & 596 \\
\hline $\mathrm{Na}$ & & 31 & 30 \\
\hline $\mathrm{P}$ & & 528 & 503 \\
\hline $\mathrm{Si}$ & & 358 & 341 \\
\hline
\end{tabular}

${ }^{a}$ Elemental concentrations calculated. Ash content estimated assuming formation of potassium carbonate upon slow additive heating to $550{ }^{\circ} \mathrm{C}$.

was used as the additive due to its low hygroscopy compared to $\mathrm{K}_{2} \mathrm{CO}_{3}$. The low hygroscopy and lower potassium content per mass unit thus minimizes the error from weighing, and accurate potassium addition levels can be obtained. $\mathrm{KHCO}_{3}$ is expected to decompose into $\mathrm{KOH}$ and $\mathrm{CO}_{2}$ upon rapid heating to high process temperatures, components which are gas-phase species common in gasification environments. Then, $5 \%$ by weight of finely ground powder was dry-mixed with bark powder; the fuel composition with and without the additive is presented in Table 1.

2.2. Reactor and Sampling. Entrained flow reactors (EFR) allows for high heating rates and temperatures similar to those found in industrial-scale systems. An EFR was used in this study to carry out particle-wall interaction experiments when gasifying a pulverized bark fuel. The reactor design has been described in detail previously, ${ }^{16,17}$ and only the details vital for this study are outlined below. The reactor consisted of a main alumina ceramic tube with $70 \mathrm{~mm}$ inner diameter and a total height of $2100 \mathrm{~mm}$. Perpendicular ports allowing insertion of an ash sampling probe and also providing optical access (Figure 1a) were located 700 and $1400 \mathrm{~mm}$ from the top. Gas and fuel particles were supplied from the top, using a primary gas flow of $9 \mathrm{~L}_{\mathrm{n}} / \mathrm{min}$ air and a shroud flow of $1 \mathrm{~L}_{\mathrm{n}} / \mathrm{min} \mathrm{N}_{2} .0 .75 \mathrm{~L}_{\mathrm{n}} / \mathrm{min}$ air was used as carrier gas for the solid particles, entering though a $6 \mathrm{~mm}$ diameter opening at the center of the top inlet. Reynolds number of the gas flow was estimated to 250, well within the laminar regime for a

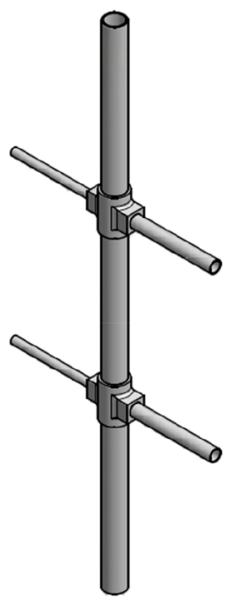

b

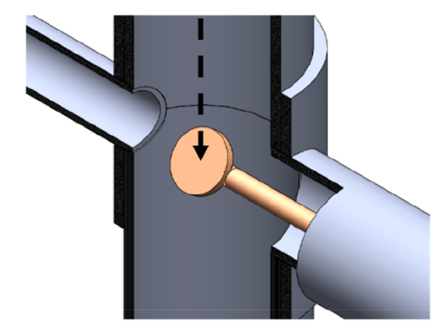

C

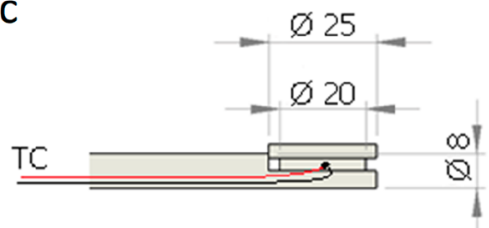

Figure 1. Schematics of reactor and probe. (a) The ceramic reactor tube and port assembly. (b) Cutout of the probe inside the assembly with particle impact vector illustrated. (c) Cross-section of impact probe with dimensions and thermocouple. Reprinted with permission from ref 17. Copyright 2018 American Chemical Society.

a tube $(\operatorname{Re}<2300)$. The global oxygen-to-fuel ratio $\lambda$ was kept at close to 0.6. The electrically heated zones of the furnace were set to isothermal temperatures ranging from 850 to $1400{ }^{\circ} \mathrm{C}$ for the different experiments. Fuel was supplied to the reactor at a rate of $200 \mathrm{~g} / \mathrm{h}$. A loudspeaker was attached to the top of the central feeding tube, emitting vibrations that ensured breakup of solid fuel particle agglomeration and counteracted plugging in the feed system. ${ }^{18}$ Ash was collected on a $25 \mathrm{~mm}$ diameter alumina collection plate mounted on a probe. The probe assembly (Figure 1c) had a built in type-S thermocouple located inside the probe, in contact with the collection plate. At all temperatures the plate was inclined so that particles would have a $30^{\circ}$ impact angle to simulate the impact of a powder flame on a reactor wall. At 1000 and $1200^{\circ} \mathrm{C}$ impact angles of 60 and $90^{\circ}$ were also used to give further details on particle adherence propensity (Figure 1b). After $30 \mathrm{~min}$ the probe was retracted from the central reaction zone while fuel feeding was maintained in order to retain a gasification atmosphere. After $10 \mathrm{~min}$ the probe temperature had cooled to $<500{ }^{\circ} \mathrm{C}$, and fuel feeding was then halted and the probe extracted.

2.3. Particle Image Velocimetry (PIV). The lower optical port of the reactor was used to collect data on particle size, shape, velocity, and vector changes by in situ PIV, and the same system was used for monitoring particles colliding with the noncooled impact probe at different angles. The silhouette of a particle was captured and particles were matched between frames, the distance traveled calculated from the scale of the image and the time it took to travel this distance given by the frame rate, and thus residence time was approximated. ${ }^{19}$ The optical system used was a LaVision ParticleMaster with a long distance microscope, the details are described in previously published work. ${ }^{20}$ Data on particle shape and size were collected and used to calculate a $3 \mathrm{D}$ equivalent diameter $D_{\text {eq }}{ }^{14,21}$ The sphereequivalent volume based on $D_{\text {eq }}$ of each particle was calculated, sorted in ascending order and the total was summarized. The size corresponding to $50 \%$ of the volume was used as the characteristic particle size. Deposit layer build-up was 

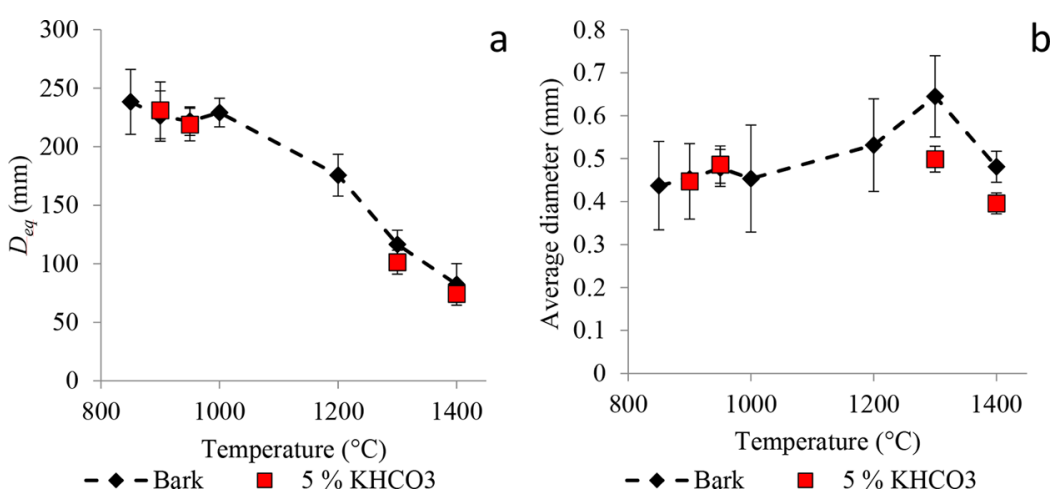

Figure 2. (a) Average particle diameter as a function of temperature. (b) Particle velocity as a function of temperature. $0 \%$ or $5 \%$ indicate amount of $\mathrm{KHCO}_{3}$ additive used. Error bars correspond to a $95 \%$ confidence interval.

determined by subtracting an initial reference frame from the collected frames and calculating the average layer thickness perpendicular from the plate surface.

2.4. Chemical Characterization. Samples collected on probe plates were analyzed using a scanning electron microscope (SEM, Carl Zeiss Evo LS-15) and energy-dispersive X-ray spectroscopy (EDS, Oxford Instruments X-Max $80 \mathrm{~mm}^{2}$ ) giving information both on morphology and elemental composition. SEM-EDS admits analysis of elemental compositions in heterogeneous particles, but can be considered semiquantitative due to the sample interaction volume and limitations in bulk composition analysis. Where liquid carbonate formation was observed half the sample was ground and analyzed for crystalline structures using powder X-ray diffraction (XRD) with a Bruker AXS D8Advance diffractometer in $\theta-\theta$ mode, $\mathrm{Cu} \mathrm{K} \alpha$ radiation (1.5418 ̊̊).

2.5. Thermodynamic Equilibrium Calculations. Thermodynamic equilibrium and viscosity calculations were used to assist interpretation of experimental results. They were carried out based on the fuel composition and employed a $\mathrm{O}_{2}$-to-fuel equivalence ratio $(\lambda)$ of 0.6 using FactSage $7.1^{22}$ with the databases FactPS, FToxid-SlagA, FTsalt-LCSO and FTsaltSCSO. The elemental concentrations provided in Table 1, with the exception of $\mathrm{Cl}$, were used as fuel composition input and slag composition output was calculated as a function of temperature spanning from 700 to $1400{ }^{\circ} \mathrm{C}$. Viscosity of the oxide slag was assessed using the viscosity module in Factsage 7.1, based on the calculated oxide slag composition and using the glasses database. The effective solid/liquid viscosity of the mix was approximated using the Guth-Simha equation with the phase mass fractions taking the place of volume fill fraction $\varphi$ (i.e., assuming uniform density), ${ }^{23}$ which have been reported to give satisfactory predictions at low Reynolds numbers. ${ }^{24}$ More thorough models, especially from the field of geology, are available ${ }^{25}$ but tend to require more detailed input data than what was available. No attempt at predicting the viscosity of liquid carbonates at atmospheric pressure was made due to lack of experimental data for liquid carbonates below $1 \mathrm{GPa}$.

\section{RESULTS AND DISCUSSION}

3.1. Entrained Particle Observations. Free-falling fuel particles observed at different temperatures showed similar trends with regards to particle size and velocity both with and without additive. Results using an impact angle of $30^{\circ}$ are presented in Figure 2a,b. The average diameter decreased with higher temperature (Figure 2a) but the average velocity of observed particles increased (Figure $2 b$ ). Increasing temper- atures lead to faster particle conversion and thermal gas expansion, which increases particle velocities. The particle velocity decreased at $1400{ }^{\circ} \mathrm{C}$ compared to $1300{ }^{\circ} \mathrm{C}$ both with and without additive, though the reasons for this require further study.

Addition of 5 wt. $\% \mathrm{KHCO}_{3}$ had no significant impact on particle diameter; velocity was unaffected at 900 or $950{ }^{\circ} \mathrm{C}$ but a velocity reduction was observed at 1300 and $1400{ }^{\circ} \mathrm{C}$ (Figure $2 \mathrm{~b})$. This reduction results in a slightly longer residence time required for entrained particles to reach the observation port. A possible explanation for the velocity reduction is that the additive increases fuel particle conversion ${ }^{26,27}$ but that the resulting char or ash became more porous (i.e., had lower density). This would reduce char particle slip speed while maintaining their optical diameter. At $1300-1400{ }^{\circ} \mathrm{C}$ a marked reduction in emitted light from the flame was also observed when using additives, though not quantitatively measured. This could be related to a reduction in soot formation ${ }^{10}$ but was beyond the scope of this paper.

3.2. Deposit Build-Up. Ash deposit growth rate was optically monitored in situ by measuring the distance from the probe surface to the silhouette of the ash layer, Figure 3. The impact of the initial particles impacting the probe surface was optically monitored and it was observed how some small particles followed the deflecting gas flow, but also how most particles impacting the surface tended to stick at temperatures of $1000{ }^{\circ} \mathrm{C}$ and above. Below that temperature only some particles adhered to the surface. The calcium rich bark ash, mainly

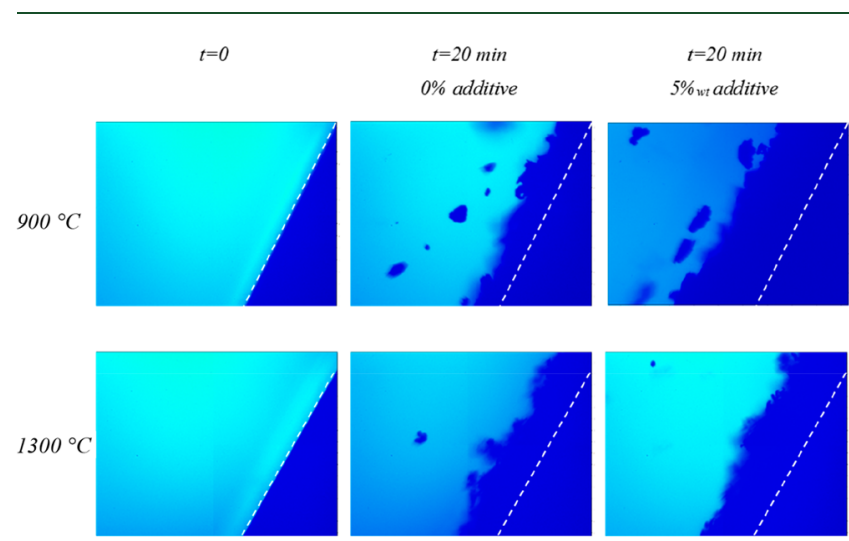

Figure 3. Probe surface with deposits at different temperatures and with/without additive. White dashed line indicates probe surface. Image size $4 \times 5 \mathrm{~mm}$. 

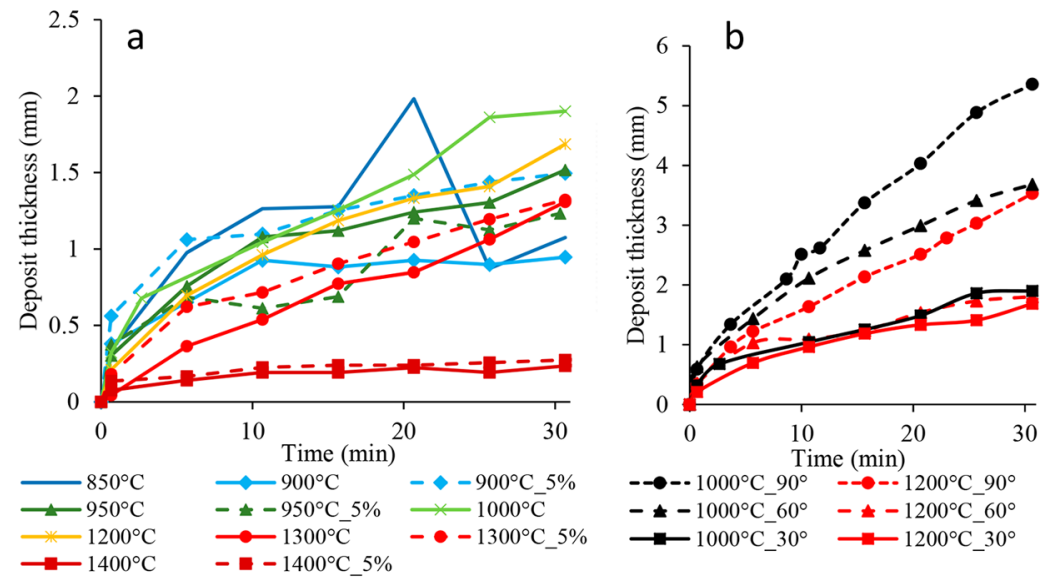

Figure 4. (a) Deposit layer thickness buildup over time at a $30^{\circ}$ impact angle. (b) Deposit layer thickness over time as a function of impact angle and temperature. The first number in series name indicates temperature $\left({ }^{\circ} \mathrm{C}\right)$, and the second number (if present) indicates either amount of additive $(\mathrm{a})$ or impact angle (b).

consisting of dry ash particles, formed a loose but adherent layer with enough intra-particle forces to form a deposit layer with no signs of spalling during the $30 \mathrm{~min}$ exposures, except at $850{ }^{\circ} \mathrm{C}$ where the deposits collapsed, explaining the sharp decrease in deposit thickness after 25 min (Figure 4a). This differs from previous studies ${ }^{4,5}$ where fuel particles rich in silicon formed melts, initiating a deposit build-up.

For the experiments at $900{ }^{\circ} \mathrm{C}$ without additive, impacting ash particles were observed to have an abrasive effect on previously formed deposits, leading to the formation of a semisteady state. Using additives at $900{ }^{\circ} \mathrm{C}$ yielded to faster deposit build-up, and it also continued to build throughout the $30 \mathrm{~min}$ experiment. The surface appeared molten, though no general downward movement of particles trapped in the melt could be observed, possibly explained by a large amount of solid particles submerged in the melt increasing the overall viscosity. ${ }^{28}$ At $1300{ }^{\circ} \mathrm{C}$ initial build-up appeared to be slightly faster using additive, but at the end of the experiment no significant difference in deposit layer thickness could be observed. At 1400 ${ }^{\circ} \mathrm{C}$ the presence of additive did not affect deposit build-up. Deposit growth rates increased with increasing temperature, reaching a maximum build-up rate $1000{ }^{\circ} \mathrm{C}$, possibly due to abrasive effects from new particles subsiding, while the size of the impacting ash particles was still maintained (compare Figure 2a). As the temperature increased past $1000^{\circ} \mathrm{C}$ the growth rate decreased, reaching a clear minimum at $1400^{\circ} \mathrm{C}$.

A positive correlation was found between deposit growth rate and increasing impact angle (Figure $4 \mathrm{~b}$ ). The $90^{\circ}$ impact angle yielded a maximum build-up rate for both 1000 and $1200{ }^{\circ} \mathrm{C}$, explained by stickiness being a minor factor when using a horizontally placed probe. The increased build-up rate at 1000 ${ }^{\circ} \mathrm{C}$ is explained by larger particles impacting the plate (Figure 2a). At $1000^{\circ} \mathrm{C}$ the impact angle was clearly an important factor explaining deposit build-up rate and is negatively correlated with particle impact velocity, supporting previously published theories. ${ }^{29,30}$ This also indicates that not all particles that impact the surface adhere, either due to not being sticky enough or that the abrasive effect is still significant. No difference in build-up rate was observed for angles between $30^{\circ}$ and $60^{\circ}$ at $1200^{\circ} \mathrm{C}$. The ash particles may be sticky enough that deflection is not an influential factor at this temperature. Using the steepest impact angle of $30^{\circ}$ and $1000{ }^{\circ} \mathrm{C}$ and also $30^{\circ} / 60^{\circ}$ impact angle at 1200 ${ }^{\circ} \mathrm{C}$, equal deposit build-up rates were observed.
3.3. Deposited Ash Properties. The ash particle shapes and chemical composition were not uniform. Three distinct categories of particles were observed in addition to the carbonate melt that formed while using 5 wt. \% $\mathrm{KHCO}_{3}$ additive (Figure $5 \mathrm{a}-\mathrm{c}$ ). The categories can be distinguished as porous grains, spherical particles, and large melts. The main bulk of ash consisted of porous grains for all temperatures and impact angles (Figure 5a). The spherical particles, that may have been molten at some point, were also found in all experiments (Figure $5 b)$. Large melts rich in silicon (30-50 wt. \% Si, O-/C-free basis) and containing potassium (25-40 wt. \%) were also observed (Figure 5c). These melts deviate markedly from the raw fuel and other ash particles and were therefore interpreted as originating from silicon rich mineral inclusions forming a potassium silicate melt. Since the fate of silicates in entrained flow gasification of bark have been previously investigated, ${ }^{17,31}$ these silicate melt particles were omitted from further analysis.

The addition of $\mathrm{KHCO}_{3}$ additive had a large effect at 900$950{ }^{\circ} \mathrm{C}$, resulting in a combined melt dominated by carbonates where no distinct particle classes could be observed (Figure $5 \mathrm{~d}$ ). Conversely, at $1300-1400{ }^{\circ} \mathrm{C}$ grains and spheres were readily identifiable even when employing additive, see Figure 5e,f. At this temperature the additive also resulted in raised potassium levels for both types of particle compared to the experiments without additive, though not as notable as at $900-950{ }^{\circ} \mathrm{C}$.

The bulk of the ash consisted of apparently nonmolten porous grains (Figure 5a) with a major ash element composition similar to that presented for bark in Table 1, with the exception of lower potassium content with increasing temperature. Only at $1400^{\circ} \mathrm{C}$ had the grains undergone distinctly different ash transformation reactions observed as a relatively higher phosphorus content for ash particles formed both with and without additive.

Average elemental composition of collected samples from bark combustion without additive are provided in Figure 6a. The ash was dominated by calcium at all temperatures which is consistent with the fuel composition. A trend of decreasing potassium concentrations with increasing process temperature was observed. Only trace amounts of potassium was detected at $1200{ }^{\circ} \mathrm{C}$ and above, which could lead to less sticky ash that would explain the lower build-up rate observed. The presence of potassium can be associated with the formation of small amounts of melts, which would also explain why deposit buildup was observed to form at higher rates during the $1000{ }^{\circ} \mathrm{C}$ 

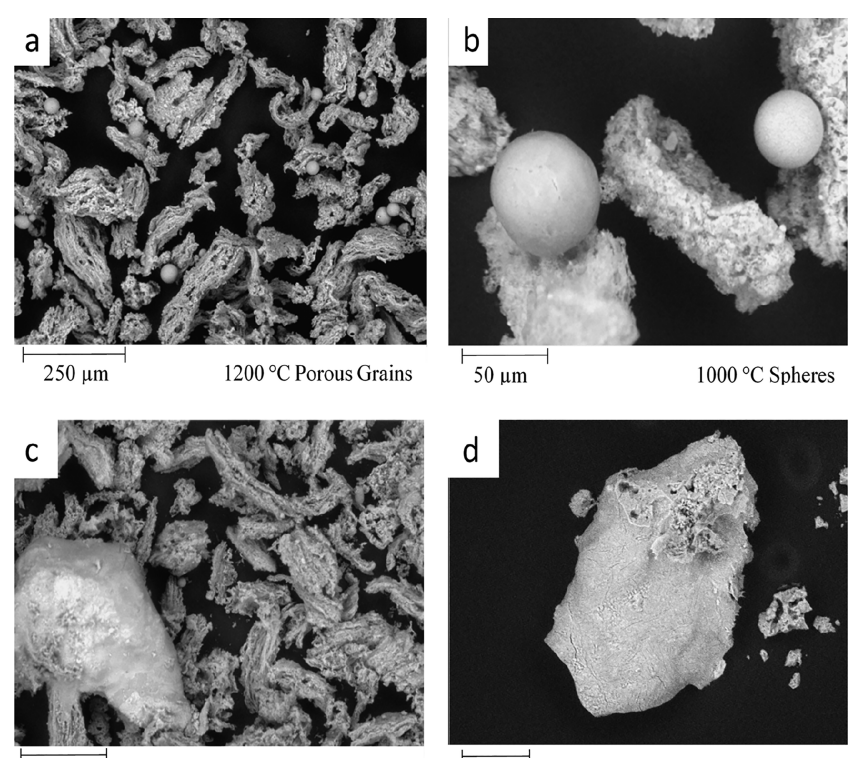

$250 \mu \mathrm{m}$

$1200{ }^{\circ} \mathrm{C}$ Si-rich melt
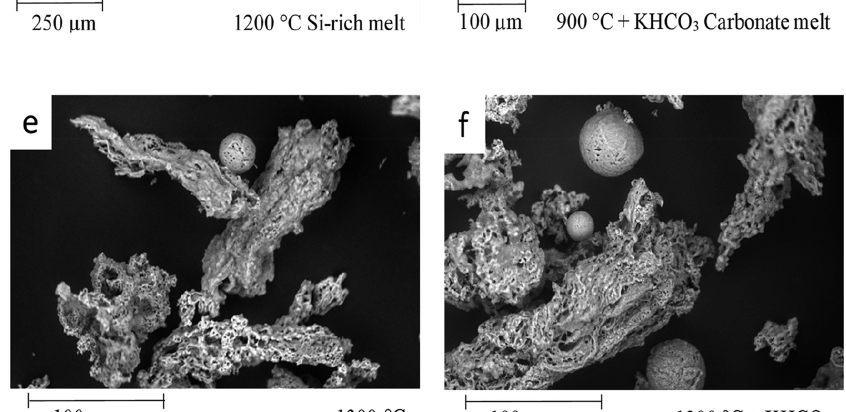

$100 \mu \mathrm{m}$

$1300^{\circ} \mathrm{C}$

$100 \mu \mathrm{m}$

$1300{ }^{\circ} \mathrm{C}+\mathrm{KHCO}_{3}$

Figure 5. Overview of ash particle categories depending on experimental parameters; note the difference in scale. (a) Bulk ash deposits consisting mainly of porous grains. (b) Spherical particles dominated by $\mathrm{Ca}$ and P. (c) Large melt in the bottom left is rich in $\mathrm{Si}$ and $\mathrm{K}, \mathrm{Si}$ likely originating from mineral inclusions. (d) Large melt rich in $\mathrm{K}$ formed with $5 \mathrm{wt}$. $\% \mathrm{KHCO}_{3}$ additive (e) $1300^{\circ} \mathrm{C}$. (f) $1300{ }^{\circ} \mathrm{C}+5$ wt. $\% \mathrm{KHCO}_{3}$.

experiments compared to the $1200{ }^{\circ} \mathrm{C}$ experiments. Small amounts of melt would also reduce abrasive effects from new particles impacting older deposits.

The elemental composition of the collected deposits with $\mathrm{KHCO}_{3}$ is provided in Figure $6 \mathrm{~b}$ to elucidate the effect of added potassium. At $900-950{ }^{\circ} \mathrm{C}$ the addition of $\mathrm{KHCO}_{3}$ additive yielded deposits dominated by potassium, while at 1300-1400 ${ }^{\circ} \mathrm{C}$ the additive gave slightly elevated potassium content. The elevated potassium content at $1400{ }^{\circ} \mathrm{C}$ could be due to the slightly higher silicon content. However, the presence of potassium silicates does not adequately explain the elevated potassium content also observed at $1300{ }^{\circ} \mathrm{C}$. Likely the abundance of gas-phase potassium species prevented full evaporation of potassium bound in the deposits at 1300-1400 ${ }^{\circ} \mathrm{C}$.

The influence of impact angle on chemical composition of ash particles at different temperatures is shown in Figure 6c. The main observation is that impact angle had an effect on potassium content in the deposit at $1000{ }^{\circ} \mathrm{C}$. A higher impact angle leads to more potassium being retained in the deposits, explained by either a difference in average chemical and physical properties of the impacting particles or possibly boundary layer gas interactions. A high impact angle leads to lower gas velocity in the immediate vicinity of the ash layer and leads to rapid particles trajectory changes as the gas moves past the plate. This implies that potassium was overrepresented in the smallest fraction of particles, as these will be most affected by rapid gas flow direction changes. The local low gas velocity above the deposits could also have an impact on partial pressures of potassium-containing gas species. It was considered whether the heaviest individual particles could explain the increased potassium content, since they were comprised by silicon-rich mineral inclusions prone to forming sticky potassium silicates. However, the relative silicon content in the deposits did not vary with impact angle, so this is an unlikely explanation for the increased potassium content at higher impact angles.

Since slag formation is a crucial parameter for entrained flow gasification, the calculated share of melt in the bulk ash is discussed below. The chemical composition of ash and slag at temperatures between 700 and $1400{ }^{\circ} \mathrm{C}$ is presented in Figure 7a,b. A large share of potassium is expected to exist in liquid and gas phase compounds between 800 and $950{ }^{\circ} \mathrm{C}$ in gasification of bark (see Figure $7 \mathrm{~b}$ ). The predicted liquidus phase mainly consists of liquid carbonates at $800-900{ }^{\circ} \mathrm{C}$, dominated by $\mathrm{K}_{2} \mathrm{CO}_{3}$ and $\mathrm{CaCO}_{3}$. Above $900{ }^{\circ} \mathrm{C}$ no potassium is expected in the liquid phase due to thermal decomposition of potassium carbonate. The calculations indicate that solid ash composition is not expected to change as temperature increases from 950 to $1040^{\circ} \mathrm{C}$, and above this temperature an oxide melt will form.
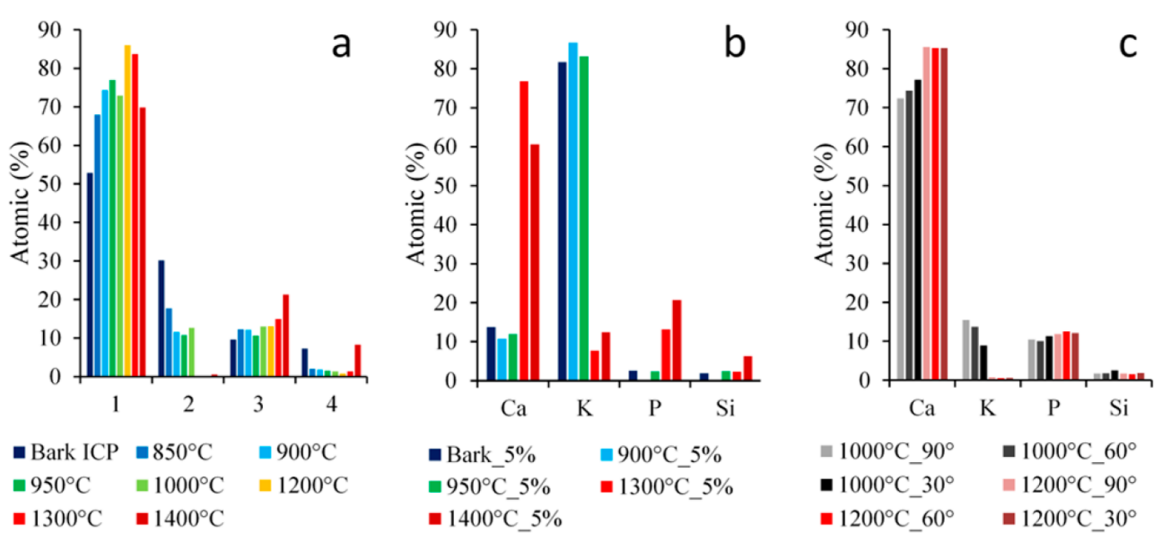

Figure 6. (a) Average atomic composition of bark and resulting deposits without $\mathrm{KHCO}_{3}$ additive. (b) Average atomic composition of bark and resulting deposits with $\mathrm{KHCO}_{3}$ additive. (c) Average atomic composition of deposits formed at different impact angles. All figures reported on $\mathrm{O}$ - and C-free basis. 

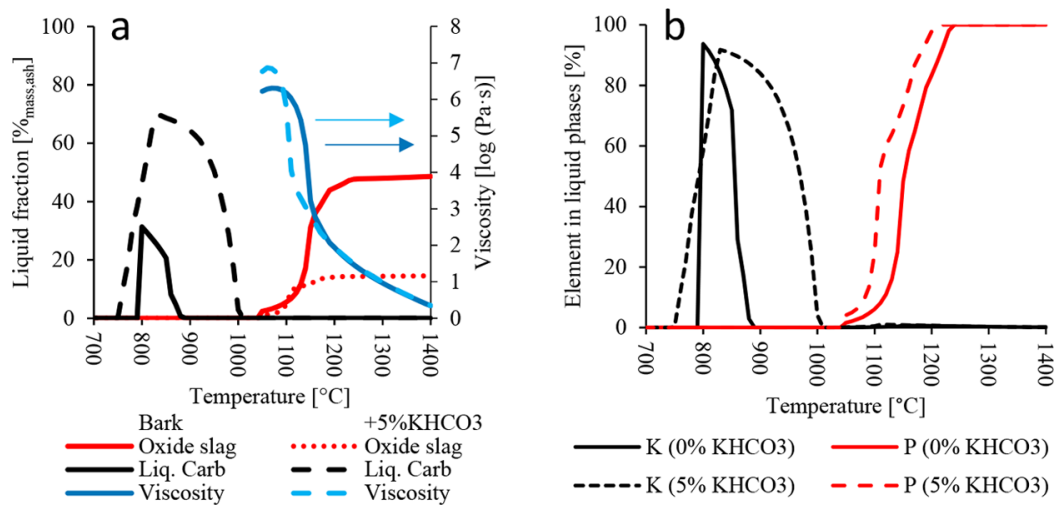

Figure 7. (a) Calculated melt amount (carbonates/slag) relative to amount of ash $\mathrm{ds}_{\mathrm{ds}}$ and calculated mix viscosity using $0 / 5 \mathrm{wt} . \% \mathrm{KHCO}_{3}$. Viscosity of carbonate melt is omitted due to lack of data. (b) Temperature dependence of equilibrium liquid-phase potassium and phosphorus compounds.

Equilibrium calculations including $\mathrm{KHCO}_{3}$ (dashed lines) indicate that the additive should contribute strongly to carbonate formation between 750 to $1000{ }^{\circ} \mathrm{C}$, which matches experimental observations. It was further predicted that the additive would only have a marginal effect on the oxide melt formation expected from $1040{ }^{\circ} \mathrm{C}$ and above. The measured potassium contents between 1300 and $1400{ }^{\circ} \mathrm{C}$ (Figure 6b) was not predicted by the equilibrium calculations. Note that the apparent reduced amount of oxide slag when using additive in Figure $7 \mathrm{a}$ is due to the scale being relative to ash forming elements on a dry substance basis.

Phosphorus is predicted to be present as $\mathrm{Ca}_{5}\left(\mathrm{PO}_{4}\right)_{3} \mathrm{OH}-$ (solidus) throughout the temperature range until oxide melt formation starts $>1040{ }^{\circ} \mathrm{C}$, above which phosphorus dissolves into the oxide melt, Figure $7 \mathrm{~b}$. The observed and calculated potassium-content in the deposits differ by a temperature offset of approximately $100{ }^{\circ} \mathrm{C}$, an indication that the deposits did not reach equilibrium. The lack of liquid phases between 900 and $1040{ }^{\circ} \mathrm{C}$ implies that only a dry ash layer would form, yet Figure $4 \mathrm{a}$ shows this being the temperature span where deposit buildup reaches a maximum. The high stability of calcium phosphates could explain the spherical particles observed in the general bulk ash, see Figure $5 \mathrm{~b}$.

The composition of spherical particles was investigated by SEM-EDS after encasing in epoxy, cutting, and polishing. The observed distribution of selected elements can be found in Figure 8. Elements were found to be evenly distributed in the
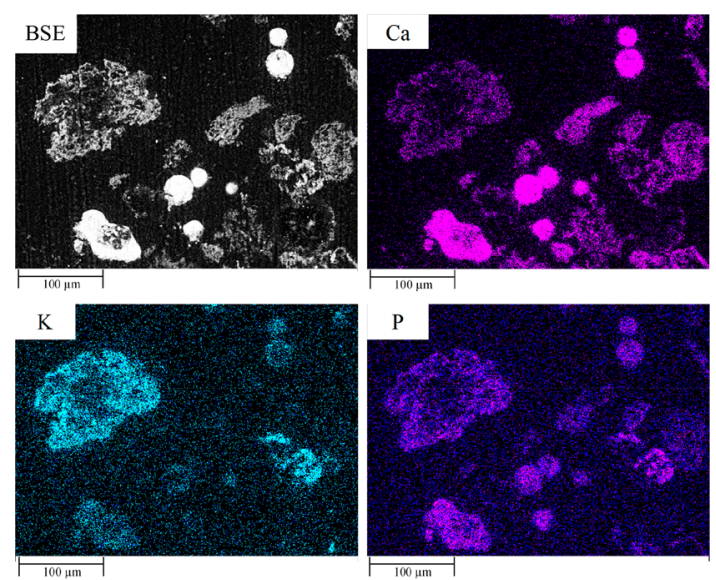

Figure 8. SEM-EDS map analysis of deposits collected at $1000{ }^{\circ} \mathrm{C}$ (without additive). spherical particles, and potassium is mainly associated with the grains. The even distribution suggests that the spherical particles were at some point at least partially molten. Omitting carbon and oxygen, the spherical particles were dominated by calcium throughout the temperature range.

In bark combustion at $850{ }^{\circ} \mathrm{C}$ the spheres had an average phosphorus content of $27 \mathrm{wt}$. \% on an $\mathrm{O}$ - and $\mathrm{C}$-free basis which dropped to a minimum of $10 \mathrm{wt} . \%$ at $1000-1200^{\circ} \mathrm{C}$, to increase to 20 wt. $\%$ at $1400{ }^{\circ} \mathrm{C}$. Irregular but dense grains with a phosphorus content similar to the spherical particles $(\sim 24-28$ wt. \%) were observed at $850{ }^{\circ} \mathrm{C}$ (Figure 9a) and these were not
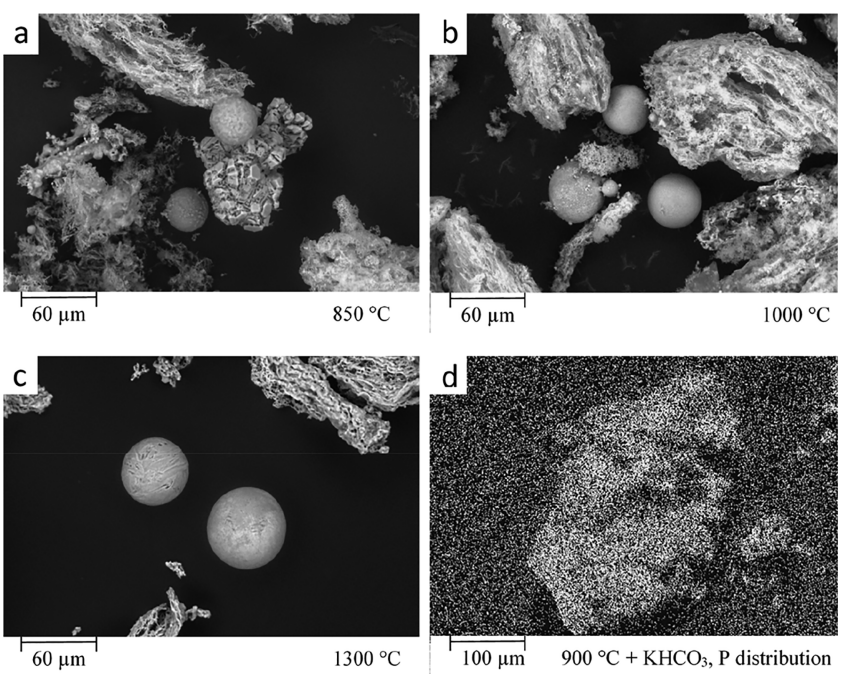

Figure 9. Phosphorus-rich spheres in bark deposits without additive and possible precursors: (a) the irregular shape between the spheres has a similar composition as the spheres; (b and c) spheres exhibited no visual change with increasing temperature; and (d) phosphorus distribution in carbonate melt formed at $900{ }^{\circ} \mathrm{C}$ using $\mathrm{KHCO}_{3}$ additive, particle previously presented in Figure 5(d).

encountered at higher temperatures. Spherical particles rich in phosphorus have previously been reported in fly ash from both coal and biomass, ${ }^{32}$ those often having a so-called "pomegranate" inner structure, something not observed here (Figure 8). Potential pathways for potassium phosphate to interact with calcium have been presented in previous studies, ${ }^{33}$ but the high phosphorus content made accurate estimations of melting point and melt fraction difficult since detailed thermodynamic data are essentially missing in that region. ${ }^{34}$ 
The P-rich spheres could be stable residual ash compounds, such as $\mathrm{Ca}_{5}\left(\mathrm{PO}_{4}\right)_{3} \mathrm{OH}$, formed in short-lived liquid carbonates. As the carbonates decompose the less volatile elements will remain, forming a homogeneous solid. It is known that the melting points of calcium phosphates are high, which makes it likely that the spheres are the result of an intermediate state. Supporting this interpretation is the observation that phosphorus was evenly distributed in the carbonate melts formed at $900{ }^{\circ} \mathrm{C}$ using additive (Figure 9d). This indicates a mobility of phosphorus which would be facilitated by melt formation.

The carbonate melt formed on the plate at $900{ }^{\circ} \mathrm{C}$ using 5 wt. $\% \mathrm{KHCO}_{3}$ was removed from the plate surface and analyzed for crystalline compounds using $\mathrm{XRD}$. The crystalline share of the melt was dominated by 50 wt. \% K-carbonates $\mathrm{K}_{2} \mathrm{CO}_{3}, \mathrm{~K}_{2} \mathrm{CO}_{3}$. $1.5 \mathrm{H}_{2} \mathrm{O}$, and $\mathrm{KHCO}_{3}$ (kalcinite); 33 wt. \% of $\mathrm{K}_{2} \mathrm{Ca}\left(\mathrm{CO}_{3}\right)_{2}$ in the two crystalline forms bütschliite and fairchildite; and $12 \mathrm{wt}$. $\% \mathrm{KAl}_{6} \mathrm{O}_{9.5}$, see Supplementary $\mathrm{S} 1$. Phosphorus was found in carbonate apatite $\left(\mathrm{Ca}_{9.9}\left[\left(\mathrm{PO}_{4}\right)_{6}\left(\mathrm{CO}_{3}\right)_{0.9}\right]\right)$ at low but detectable levels (3 wt. \%), a compound previously identified in the relevant temperature range. ${ }^{35}$ The interior of the carbonate layer was analyzed using SEM/EDS, with resulting average elemental compositions in good agreement with that detected by crystalline compounds in XRD, which supports the XRD data interpretation.

From the perspective of the $\left(\mathrm{K}_{2} \mathrm{O}-\mathrm{Na}_{2} \mathrm{O}\right)+(\mathrm{CaO}-\mathrm{MgO})+$ $\mathrm{P}_{2} \mathrm{O}_{5}$ system, the spherical particles appear to be situated along a curved path with both its lower-temperature origin and hightemperature composition far removed from the bulk composition of the raw fuel (i.e., closer to the $\mathrm{P}_{2} \mathrm{O}_{5}$ corner). Relative phosphorus content reaches a minimum at $950{ }^{\circ} \mathrm{C}$ then increased again at $1300{ }^{\circ} \mathrm{C}$ and above; see Figure 10. The

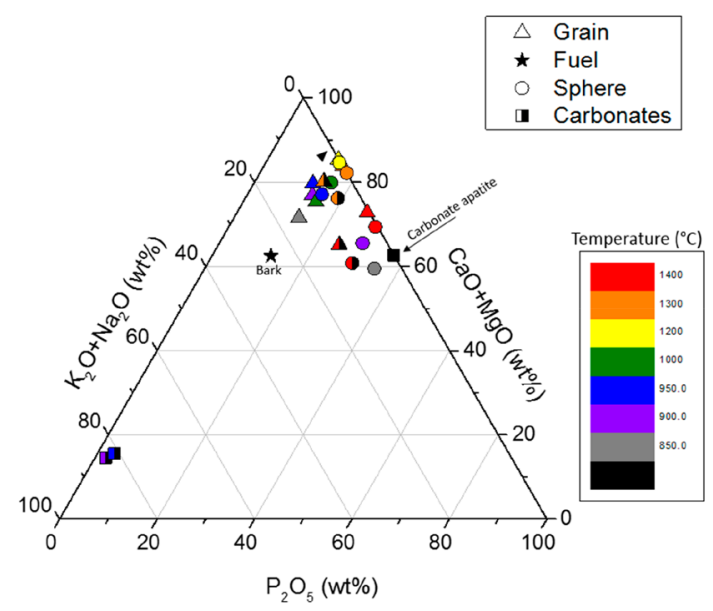

Figure 10. Ternary diagram of $\left(\mathrm{K}_{2} \mathrm{O}+\mathrm{Na}_{2} \mathrm{O}\right)-(\mathrm{CaO}+\mathrm{MgO})-$ $\left(\mathrm{P}_{2} \mathrm{O}_{5}\right)$. Symbols indicate the average value of SEM-EDS analysis of spheres, grains, carbonate deposits and the raw fuel composition (given by ICPMS analysis). Symbols with a black right side indicate experiments using $5 \mathrm{wt}$. $\% \mathrm{KHCO}_{3}$ additive.

proposed formation mechanism for solid spheres from calcination of carbonate apatite results in a reasonable position on the diagram. This relation speaks in favor of the carbonate apatite being a likely precursor to the phosphate rich spheres found in bark ash deposits. However, it is important to keep in mind that the carbonate apatite was detected in deposits from the experiment at $900{ }^{\circ} \mathrm{C}$ using additive, due to the spheres themselves being too small for separate XRD-analysis. As the detected carbonate apatite contained no potassium despite the extremely potassium-rich carbonate melt it was found in, the interaction between potassium and phosphorus in the calciumrich spheres may be minimal.

\section{CONCLUSIONS}

The present study aimed at experimentally determining the influence of increased potassium content on ash properties during entrained flow gasification of calcium rich spruce bark. Significant amounts of liquid carbonates were formed between 900 and $950{ }^{\circ} \mathrm{C}$ using the $\mathrm{KHCO}_{3}$ additive, but due to inclusions of solid ash particles the desired flowing assisted by the presence of carbonate melt was not achieved. A constant deposit thickness was achieved at $900{ }^{\circ} \mathrm{C}$ without additive due an equal rate of adhesion and abrasive effect from impacting solid ash particles. This would in theory allow for the operation of dry ash gasification using bark, though at both 850 and $950{ }^{\circ} \mathrm{C}$ significant deposit build-up was observed, making this unfeasible in practice. Some potassium was retained in the ash even at 1300 ${ }^{\circ} \mathrm{C}$ and above using $\mathrm{KHCO}_{3}$ additive, likely in stable calcium potassium phosphates, which were not predicted by thermochemical equilibrium calculations due to missing thermodynamic data.

The impact angle was identified as an influential for deposit properties at temperatures below $1000{ }^{\circ} \mathrm{C}$; high impact angles resulted in potassium depletion which could be of importance for slag layer formation and hence slag flow and protection of refractory walls.

At higher temperatures, strong indications of rapid local melt formation in the ash particles including complex phosphatecarbonates were observed as spherical ash particles. The initial stage of formation is likely a carbonate apatite melt which may be facilitated by the calcium oxalates crystals prevalent in bark. The calcium-rich phosphates formed after calcination permits potassium inclusion with $\mathrm{KHCO}_{3}$ additive use at the highest temperatures investigated. They need to be taken into consideration when investigating pathways to improve fuel flexibility in entrained flow gasification. These results identified a previously unknown challenge for slag flowing properties in entrained flow gasification of fuel blends with high potassium and calcium in relation to phosphorus since these particles may reduce slag flowability even at high temperatures. The results have direct relevance for determining suitable fuels or fuel mixtures to be used for successful operation of slagging entrained flow gasifiers.

\section{ASSOCIATED CONTENT}

\section{Supporting Information}

The Supporting Information is available free of charge at https://pubs.acs.org/doi/10.1021/acs.energyfuels.0c00753.

Powder X-ray diffraction and supplementary Table 1 and Figure 1 (PDF)

\section{AUTHOR INFORMATION}

\section{Corresponding Author}

Markus Broström - Department of Applied Physics and Electronics, Thermochemical Energy Conversion Laboratory, Umeå University, SE-901 87 Umeå, Sweden; ํorcid.org/ 0000-0003-1095-9154; Email: markus.brostrom@umu.se 


\section{Authors}

Per Holmgren - Department of Applied Physics and Electronics, Thermochemical Energy Conversion Laboratory, Umeå University, SE-901 87 Umeå, Sweden

Nils Skoglund - Department of Applied Physics and Electronics, Thermochemical Energy Conversion Laboratory, Umeå University, SE-901 87 Umeå, Sweden; 이이이.org/00000002-5777-9241

Rainer Backman - Department of Applied Physics and Electronics, Thermochemical Energy Conversion Laboratory, Umeå University, SE-901 87 Umeå, Sweden

Complete contact information is available at: https://pubs.acs.org/10.1021/acs.energyfuels.0c00753

\section{Notes}

The authors declare no competing financial interest.

\section{ACKNOWLEDGMENTS}

The authors would like to thank Markus Carlborg and Dan Boström for their aid in acquiring and subsequently interpreting XRD patterns. We acknowledge Umeå Core Facility for Electron Microscopy (UCEM) for technical support, National Microscopy Infrastructure (NMI) for EM access, and Kempe foundations for instrument funding support. The authors also gratefully acknowledge financial support from the Swedish strategic research program Bio4Energy, the Swedish Research Council (Grants 2014-5041 and 2017-0533), and the Swedish Energy Agency through the Swedish Gasification Center and through the Catalytic Entrained Flow Gasification of Biomass project.

\section{REFERENCES}

(1) Niu, Y.; Tan, H.; Hui, S. e. Ash-related issues during biomass combustion: Alkali-induced slagging, silicate melt-induced slagging (ash fusion), agglomeration, corrosion, ash utilization, and related countermeasures. Prog. Energy Combust. Sci. 2016, 52, 1-61.

(2) Collot, A.-G. Matching gasification technologies to coal properties. Int. J. Coal Geol. 2006, 65 (3), 191-212.

(3) Carlsson, P.; Ma, C.; Molinder, R.; Weiland, F.; Wiinikka, H.; Öhman, M.; Öhrman, O. Slag Formation during Oxygen-Blown Entrained-Flow Gasification of Stem Wood. Energy Fuels 2014, 28 (11), 6941-6952.

(4) Ma, C.; Backman, R.; Öhman, M. Thermochemical Equilibrium Study of Slag Formation during Pressurized Entrained-Flow Gasification of Woody Biomass. Energy Fuels 2015, 29 (7), 4399-4406.

(5) Ma, C.; Weiland, F.; Hedman, H.; Boström, D.; Backman, R.; Öhman, M. Characterization of Reactor Ash Deposits from Pilot-Scale Pressurized Entrained-Flow Gasification of Woody Biomass. Energy Fuels 2013, 27 (11), 6801-6814.

(6) Vassilev, S. V.; Baxter, D.; Andersen, L. K.; Vassileva, C. G. An overview of the chemical composition of biomass. Fuel 2010, 89 (5), 913-933.

(7) Boström, D.; Skoglund, N.; Grimm, A.; Boman, C.; Öhman, M.; Broström, M.; Backman, R. Ash Transformation Chemistry during Combustion of Biomass. Energy Fuels 2012, 26 (1), 85-93.

(8) Berdugo Vilches, T.; Maric, J.; Knutsson, P.; Rosenfeld, D. C.; Thunman, H.; Seemann, M. Bed material as a catalyst for char gasification: The case of ash-coated olivine activated by $\mathrm{K}$ and $\mathrm{S}$ addition. Fuel 2018, 224, 85-93.

(9) Furusjö, E.; Ma, C. Y.; Ji, X. Y.; Carvalho, L.; Lundgren, J.; Wetterlund, E. Alkali enhanced biomass gasification with in situ $S$ capture and novel syngas cleaning. Part 1: Gasifier performance. Energy 2018, 157, 96-105.

(10) Umeki, K.; Häggström, G.; Bach-Oller, A.; Kirtania, K.; Furusjö, E. Reduction of Tar and Soot Formation from Entrained-Flow
Gasification of Woody Biomass by Alkali Impregnation. Energy Fuels 2017, 31 (5), 5104-5110.

(11) Furusjö, E.; Jafri, Y. Thermodynamic equilibrium analysis of entrained flow gasification of spent pulping liquors. Biomass Convers. Biorefin. 2018, 8 (1), 19-31.

(12) Häggström, C.; Öhrman, O.; Rownaghi, A. A.; Hedlund, J.; Gebart, R. Catalytic methanol synthesis via black liquor gasification. Fuel Process. Technol. 2012, 94 (1), 10-15.

(13) Consonni, S.; Katofsky, R. E.; Larson, E. D. A gasification-based biorefinery for the pulp and paper industry. Chem. Eng. Res. Des. 2009, 87 (9A), 1293-1317.

(14) Holmgren, P.; Wagner, D. R.; Strandberg, A.; Molinder, R.; Wiinikka, H.; Umeki, K.; Broström, M. Size, shape, and density changes of biomass particles during rapid devolatilization. Fuel 2017, 206, 342351.

(15) Yao, X. W.; Zheng, Y.; Zhou, H. D.; Xu, K. L.; Xu, Q. W.; Li, L. Effects of biomass blending, ashing temperature and potassium addition on ash sintering behaviour during co-firing of pine sawdust with a Chinese anthracite. Renewable Energy 2020, 147, 2309-2320.

(16) Wagner, D. R.; Holmgren, P.; Skoglund, N.; Broström, M. Design and validation of an advanced entrained flow reactor system for studies of rapid solid biomass fuel particle conversion and ash formation reactions. Rev. Sci. Instrum. 2018, 89 (6), 065101.

(17) Holmgren, P.; Broström, M.; Backman, R. Slag Formation during Entrained Flow Gasification: Silicon Rich Grass Fuel with KHCO3 Additive. Energy Fuels 2018, 32, 10720.

(18) Göktepe, B.; Umeki, K.; Hazim, A.; Lundström, T. S.; Gebart, R. Soot reduction in an entrained flow gasifier of biomass by active dispersion of fuel particles. Fuel 2017, 201, 111-117.

(19) Tolvanen, H.; Kokko, L.; Raiko, R. Fast pyrolysis of coal, peat, and torrefied wood: Mass loss study with a drop-tube reactor, particle geometry analysis, and kinetics modeling. Fuel 2013, 111, 148-156.

(20) Wagner, D. R.; Holmgren, P.; Skoglund, N.; Broström, M. Design and validation of an advanced entrained flow reactor system for studies of rapid solid biomass fuel particle conversion and ash formation reactions. Rev. Sci. Instrum. 2018, 89 (6), 065101.

(21) Bagheri, G. H.; Bonadonna, C.; Manzella, I.; Vonlanthen, P. On the characterization of size and shape of irregular particles. Powder Technol. 2015, 270, 141-153.

(22) Bale, C. W.; Bélisle, E.; Chartrand, P.; Decterov, S. A.; Eriksson, G.; Hack, K.; Jung, I. H.; Kang, Y. B.; Melançon, J.; Pelton, A. D.; Robelin, C.; Petersen, S. FactSage thermochemical software and databases - recent developments. CALPHAD: Comput. Coupling Phase Diagrams Thermochem. 2009, 33 (2), 295-311.

(23) Guth, E.; Simha, R. Untersuchungen über die Viskosität von Suspensionen und Lösungen. 3. Über die Viskosität von Kugelsuspensionen. Colloid Polym. Sci. 1936, 74 (3), 266-275.

(24) Happel, J. Low Reynolds number hydrodynamics: with special applications to particulate media. Low Reynolds number hydrodynamics, 1983. ISBN 978-90-247-2877-0.

(25) Mader, H. M.; Llewellin, E. W.; Mueller, S. P. The rheology of two-phase magmas: A review and analysis. J. Volcanol. Geotherm. Res. 2013, 257, 135-158.

(26) Rozas, R.; Escalona, N.; Sepulveda, C.; Leiva, K.; Chimentao, R. J.; Garcia, R.; Fierro, J. L. G. Catalytic gasification of pine-sawdust: Effect of primary and secondary catalysts. J. Energy Inst. 2019, 92 (6), $1727-1735$

(27) Arnold, R. A.; Habibi, R.; Kopyscinski, J.; Hill, J. M. Interaction of Potassium and Calcium in the Catalytic Gasification of Biosolids and Switchgrass. Energy Fuels 2017, 31 (6), 6240-6247.

(28) Cheng, N. S.; Law, A. W. K. Exponential formula for computing effective viscosity. Powder Technol. 2003, 129 (1-3), 156-160.

(29) Li, S. H.; Wu, Y. X.; Whitty, K. J. Ash Deposition Behavior during Char-Slag Transition under Simulated Gasification Conditions. Energy Fuels 2010, 24 (3), 1868-1876.

(30) Mueller, C.; Selenius, M.; Theis, M.; Skrifvars, B. J.; Backman, R.; Hupa, M.; Tran, H. Deposition behaviour of molten alkali-rich fly ashes - development of a submodel for CFD applications. Proc. Combust. Inst. 2005, 30, 2991-2998. 
(31) Ma, C.; Carlborg, M.; Hedman, H.; Wennebro, J.; Weiland, F.; Wiinikka, H.; Backman, R.; Öhman, M. Ash Formation in Pilot-Scale Pressurized Entrained-Flow Gasification of Bark and a Bark/Peat Mixture. Energy Fuels 2016, 30 (12), 10543-10554.

(32) Valentim, B.; Flores, D.; Guedes, A.; Guimaraes, R.; Shreya, N.; Paul, B.; Ward, C. R. Notes on the occurrence of phosphate mineral relics and spheres (phosphospheres) in coal and biomass fly ash. Int. J. Coal Geol. 2016, 154-155, 43-56.

(33) Skoglund, N. Ash chemistry and fuel design focusing on combustion of phosphorus-rich biomass. Thesis; Umeå University: Umeå, 2014.

(34) Lindstrom, E.; Sandstrom, M.; Boström, D.; Öhman, M. Slagging characteristics during combustion of cereal grains rich in phosphorus. Energy Fuels 2007, 21 (2), 710-717.

(35) Tonegawa, T.; Ikoma, T.; Yoshioka, T.; Hanagata, N.; Tanaka, J. Crystal structure refinement of A-type carbonate apatite by X-ray powder diffraction. J. Mater. Sci. 2010, 45 (9), 2419-2426. 